\title{
The Savannah River Environmental Technology Field Test Platform: Phase II
}

by

J. Rossabi

Westinghouse Savannah River Company

Savannah River Site

Aiken, South Carolina 29808

B. D. Riha

C. A. Eddy-Dilek

B. E. Pemberton

C. P. May

T. R. Jarosch

B. B. Looney

R. Raymond

DOE Contract No. DE-AC09-89SR18035

This paper was prepared in connection with work done under the above contract number with the U.S.

Department of Energy. By acceptance of this paper, the publisher and/or recipient acknowledges the U.S. Government's right to retain a nonexclusive, royalty-free license in and to any copyright covering this paper, along with the right to reproduce and to authorize others to reproduce all or part of the.copyrighted paper. 


\section{DISCLAIMER}

This report was prepared as an account of work sponsored by an agency of the United States Government. Neither the United States Government nor any agency thereof, nor any of their employees, make any warranty, express or implied, or assumes any legal liability or responsibility for the accuracy, completeness, or usefuiness of any information, apparatus, product, or process disclosed, or represents that its use would not infringe privately owned rights. Reference herein to any specific commercial product, process, or service by trade name, trademark, manufacturer, or otherwise does not necessarily constitute or imply its endorsement, recommendation, or favoring by the United States Government or any agency thereof. The views and opinions of authors expressed herein do not necessarily state or reflect those of the United States Government or any agency thereof. 


\section{DISCLAIMER}

Portions of this document may be illegible in electronic image products. Images are produced from the best available original document. 


\section{The Savannah River Environmental Technology Field Test Platform: Phase II (U)}


WSRC-MS-94-0255

Rev 0

\section{The Savannah River Environmental Technology Field Test Platform: Phase II (U)}

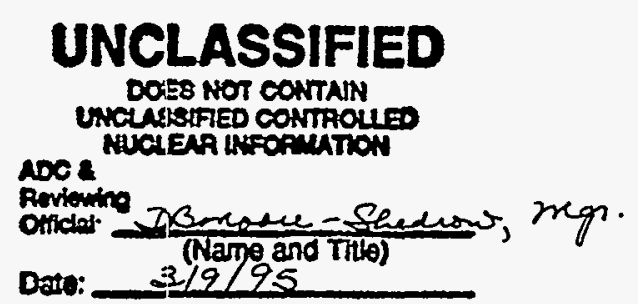

Westinghouse Savannah River Company Savannah River Site

Aiken, SC 29808

Prepared for the U.S. Department of Energy under contract no. DE-AC09-89SR18035 
WSRC-RP-94-0255

Rev 0

February 1995

\section{The Savannah River Environmental Technology Field Test Platform: Phase II (U)}

Prepared by Savannah River Technology Center-Environmental Sciences Section and the Oak Ridge Institute for Science and Education

J. Rossabi, B. D. Riha, C. P. May, B. E.Pemberton, T. R. Jarosch, R. Raymond, C.A. Eddy-Dilek and B. B. Looney

Authentication:

D.B. Moore-Shedrow, Section Manager

Authorized Derivative Classifier

Prepared for the U.S. Department of Energy under contract no. DE-AC09-89SR18035

$$
\text { ins its }
$$




\section{DISCLAIMER}

This report was prepared as an account of work sponsored by an agency of the United States Government. Neither the United States Government nor any agency thereof, nor any of their employees, makes any warranty, express or implied, or assumes any legal liability or responsibility for the accuracy. completeness, or usefulness of any information, apparatus, product, or process disclosed, or represents that its use would not infringe privately owned rights. Reference herein to any specific commercial product, process, or service by trade name, trademark, manufacturer, or otherwise does not necessarily constitute or imply its endorsement, recommendation, or favoring by the United States Government or any agency thereof. The views and opinions of authors expressed herein do not necessarily state or reflect those of the United. States "Government or any agency thereof.

This report has been reproduced directly from the best available copy.

Available to DOE and DOE contractors from the Office of Scientific and Technical Information, P. O. Box 62, Oak Ridge, TN 37831; prices available from (615) $576-8401$.

Available to the public from the National Technical Infornation Service, U. S. Deparment of Commerce, 5285 Port Royal Rd., Springfield, VA 22161 
Acknowledgments

This work was funded by the Office of Technology Development within the Department of Energy's Office of Environmental Management.

Savannah River Field Office

Technology Program Officer: J.M. Brown

Office of Technology Development

Program Manager: K.D. Gerdes 


\title{
The Savannah River Environmental Technology Field Test Platform: Phase II
}

\author{
J. Rossabi \\ Bldg. 773-42A \\ Westinghouse Savannah River Company \\ Aiken, SC 29802 \\ B. D. Riha \\ Oak Ridge Institute for Science and Education \\ Bldg. 773-42A, Westinghouse Savannah River Company \\ Aiken, SC 29802 \\ C. P. May \\ Westinghouse Savannah River Company \\ B. E. Pemberton \\ Westinghouse Savannah River Company \\ T. R. Jarosch \\ Westinghouse Savannah River Company \\ C.A. Eddy-Dilek \\ Westinghouse Savannah River Company \\ B. B. Looney \\ Westinghouse Savannah River Company \\ R. Raymond \\ Bechtel Savannah River Inc. \\ Bldg. 686-3G \\ Aiken, SC 29802
}

\begin{abstract}
The principal goal in the development of new technologies for environmental monitoring and characterization is transferring them to organizations and individuals for use in site assessment and compliance monitoring. The DOE complex has devised several strategies to facilitate this transfer including joint research projects between private industries and government laboratories or universities (CRADAs), and streamlined licensing procedures. One strategy that has been under-utilized is a planned sequence gradually moving from laboratory development and field demonstration to long term evaluation and onsite use. Industrial partnership and commercial production can be initiated at any step based on the performance, market, user needs, and costs associated with the technology. This approach allows use of the technology by onsite groups for compliance monitoring tasks (e.g. Environmental Restoration and Waste Management), while
\end{abstract}


allowing parallel research and development organizations the opportunity to evaluate the long term performance and to make modifications or improvements to the technology. This probationary period also provides regulatory organizations, potential industrial partners, and potential users with the opportunity to evaluate the technology's performance and its utility for implementation in environmental characterization and monitoring programs.

The Savannah River Technology Center (SRTC) has been developing a program to rigorously field test promising environmental technologies that have not undergone EPA equivalency testing. The infrastructure and staff expertise developed as part of the activities of the Savannah River Integrated Demonstration Program (i.e., wells, available power, conventional baseline characterization and monitoring equipment, shelter structures) allows field testing of technologies without the difficulties of providing remote field support. By providing a wellcharacterized site and a well-developed infrastructure, technologies can be tested for long periods of time to determine their appropriate applications in environmental characterization and monitoring activities. Situation specific evaluations of the technology following stringent test plans can be made in comparison with simultaneous baseline methods and historical data. This program is designed to help expedite regulatory approval and technology transfer to manufacturers and the user community.

An advisory committee has been established consisting of representatives from local and national regulatory groups, industry, universities, public interest groups, potential users, and SRTC personnel. The group helps determine the technologies that are evaluated and reviews the evaluation strategy and specific test plans for the new technology. The inclusion of local regulatory personnel in the advisory groups facilitates the use of appropriate innovative technologies in remedial facility investigations and remediation programs at SRS. Successful internal transfers of technologies at SRS from research and development to users (e.g. Environmental Restoration, Industrial Health and Hygiene) include: 1) gas chromatography using the headspace method to rapidly evaluate volatile organic contamination in water and soil samples; 2) a commercial infrared photoacoustic gas analyzer for faster and more accurate measurements; and 3) the cone penetrometer with several sensors and samplers for rapid, depth discrete contaminant measurements. These internal transfers have stimulated the use of the technologies in both onsite and offsite activities. The cone penetrometer and the headspace method are now accepted field screening techniques in most areas of the country.

As the new technologies are used, there is a larger demand for their implementation both on and offsite. This demand leads industry and users to the technologies. Successful performance of a technology as compared with baseline technologies should facilitate their acceptance as standard protocols.

\section{INTRODUCTION}

The Savannah River Site (SRS) was the host site for the Department of Energy's Office of Technology Development Integrated Demonstration Program (IDP) titled "Cleanup of Organics in Soil and Groundwater at Non-Arid Sites." During this program, an area contaminated by subsurface leaks of chlorinated organic chemicals from a process sewer line was used to demonstrate innovative environmental technologies to expedite site remediation. New drilling, characterization, monitoring, and remediation methods were combined, demonstrated, and 
evaluated from 1989 to 1993 as part of this program. A large amount of characterization data were taken using conventional characterization and monitoring technologies (e.g., soil cores, water and soil sampling, pumping tests, and tracer tests) at the Integrated Demonstration Site (IDS) to evaluate the efficiency of the remediation and to support demonstrations. Much of the data were integrated into three-dimensional visualizations for detailed conceptual models of the contaminant distributions. At the end of the IDP, the area was transferred to SRS Environmental Restoration personnel to continue cleanup operations using some of the new technologies that were demonstrated at the site. The cooperative working relation between SRS laboratory and operations personnel and the abundance of site characterization data provide the unique opportunity for experimentation and evaluation of technologies at a site undergoing remediation.

Many technologies that were not funded as part of the IDP have also been tested at the site. Developers have brought their technologies to the IDS because:

1) the site is well-characterized,

2) the types and distribution of the contaminants at the site are typical of many other contaminated sites,

3) the technical and laboratory support available (i.e., experienced staff and baseline technologies) and quick turnaround on chemical analyses,

4) the historical data available on innovative technologies tested there,

5) the availability of instrumented field laboratories and amenities (power, etc.),

6) the number of active remediation systems on site, and

7) the variety of subsurface access wells allows for identification of the appropriate niche for a given technology.

Due to the well-developed infrastructure resulting from the IDP, the site is an ideal location for short and long term evaluation of environmental characterization and monitoring technologies. The site provides a well characterized field test platform with supporting environmental professionals where innovative characterization and monitoring technologies can be demonstrated, evaluated, and implemented to facilitate transfer of these technologies.

The principal objectives of this project are to conduct comprehensive long-term field tests, short term demonstrations, and application-specific training in the use of monitoring and characterization technologies that are not currently used in EPA standard methods. The field test platform provides a forum for developers, potential users, industrial partners, and regulatory organizations to evaluate new technologies and will expedite the transfer and use of these technologies in local and national remediation projects.

The information presented here includes a description of the site, a description of the testing protocol for field vapor-phase technology evaluations, and a description of some of the technologies evaluated during FY95. A future report will provide the quantitative evaluations of these technologies. A field demonstration and training activity is scheduled for March 20-24, 1995 at SRS. 


\section{BACKGROUND}

\section{Site Description}

SRS encompasses a 300-square-mile area near Aiken, South Carolina and is located on the upper Atlantic Coastal Plain. The site is underlain by a thick wedge (approximately 1000 feet) of unconsolidated Tertiary and Cretaceous sediments that overlay the basement, which consists of Precambrian and Paleozoic metamorphic rocks and consolidated Triassic sediments (siltstone and sandstone). The younger sedimentary section consists predominantly of sand, clayey sand, and sandy clay (Eddy et al., 1991).

Groundwater flow at the site is controlled by hydrologic boundaries: flow at or immediately below the water table is to local tributaries; flow in the lower Tertiary aquifer is to the Savannah River or one of its major tributaries; and flow in the Cretaceous aquifers is toward the Savannah River. Flow in the shallow aquifers in the immediate vicinity of the Savannah River Integrated Demonstration Site is highly influenced by the eleven-well pump-and -treat recovery network (Kaback et al., 1989).

The DOE owned area contains a nuclear material production facility that has been operating since 1951. As with many large production facilities, SRS has released chemicals into the environment. These releases and early disposal practices have resulted in the contamination of the subsurface of many on site areas by a number of different compounds used in or resulting from the production process. The largest volume of contamination has been from chlorinated volatile organic compounds (CVOCs). SRS used trichloroethylene (TCE), tetrachloroethylene (PCE) and trichloroethane (TCA) until the early 1980s as metal degreasing solvents (Looney et al., 1992). Several areas on site including the demonstration site have measured elevated levels of these compounds in the groundwater. Conventional groundwater pump-and-treat systems and vapor extraction systems have been installed in several areas on site.

\section{Integrated Demonstration Site Description}

The area selected for the Savannah River Integrated Demonstration Site (SRIDS) is along an abandoned process sewer line that carried nonradioactive solvent waste to a seepage basin for 27 years beginning in 1958. Characterization data indicated that several leaks existed in the sewer line (ca 20-ft depth) which served as localized sources of contamination. The use of the sewer line was discontinued in 1985. Over two million pounds of solvent are estimated to be in the subsurface in this area (Looney et al., 1992). Seven horizontal wells were installed at the site both above and below the water table. These wells have been used in innovative remediation technology demonstrations of in situ air stripping, air sparging, bioremediation, and radio frequency heating. In addition to the large scale remediation and drilling demonstrations, over forty innovative characterization and monitoring technologies have been demonstrated at the site (WSRC, 1993). Four of the horizontal wells have been transferred to the Environmental Restoration group on site for remediation operations.

Many types of monitoring weils were installed at the SRIDS. Wells are screened in the water table aquifer and the Tertiary aquifer as well as various lithologic zones in the unsaturated zone. Each water well cluster consists of two wells, one screened in the water table and one screened in the upper sand of the Tertiary aquifer. The vadose zone well clusters consist of three piezometer wells ( $5 \mathrm{ft}$ screen lengths) at different depths targeting the edges of the major clay 
zones at the site (WSRC, 1994). Other specialized access wells have been installed including wells with stainless steel casing, wells with multiple short ( 2 feet) screened intervals, and wells with continuously screened intervals. Many continuously cored boreholes were drilled to the water table or deeper and logged. Samples for chemical and microbiological analyses were collected from the cores and used to characterize the site. Geophysical logs of the deepest boreholes $(190 \mathrm{ft}$ ) were used to create geological cross-sections (Eddy et al., 1991). More than 300 wells of various types are installed in the vicinity of the SRIDS and over 3000 wells over the whole SRS.

Historical baseline information includes concentration data (aqueous, soil, and soil gas) and hydrogeological data (permeability, porosity, water content, etc.). This database has been used as a baseline for comparing results from new monitoring and characterization technologies.

\section{STRATEGY FOR THE FIELD TEST PLATFORM}

One of the best ways to leverage the data, experience, and infrastructure developed as part ${ }^{-}$. of the SRID is to conduct field activities to test new technologies. Because of the large amount of high quality field data, comprehensive tests can be conducted to evaluate the performance of these new technologies. There are three types of field activities that are relevant to effective technology transfer: 1) short-term demonstrations, 2) long-term testing and evaluation, and 3) scenario based training. During this project we are conducting all three types of activities.

\section{Short Term Demonstrations}

Short-term demonstrations consist of initial demonstrations, and interim or final demonstrations. Initial demonstrations of prototype or newly developed instruments are typically the first field experiences of the technology and occur shortly after labolatory bench testing. During this activity, the technology is operated in the field by the developers of the technology (experts) who try to confirm the successful performance of the technology already achieved in the laboratory. This activity usually illuminates both the technical issues and the fielding and logistical issues associated with the use of the instruments in the field. Technical issues (e.g., matrix effects and interferences, required dynamic range), and logistical issues (e.g., interface with the access point, supporting equipment required in the field) are normally determined here. This activity helps to clarify and refocus preconceived notions about the application and niche of the technology and provides the developer with the opportunity to modify the technology to more closely fit the appropriate niche. For these demonstrations, SRS scientists help instrument developers determine the appropriate applications for field testing based on their knowledge of the site geology, contaminant distribution, and previous tests conducted.

Interim or final demonstrations are conducted after or during long term testing of the technology. For these activities, the technology is operated by real users (less than experts) and should only be applied in the appropriate measurement scenarios. It is important for the developer to realize that most technologies can not be applied to every rneasurement application. These demonstrations must target the determination of operational parameters such as setup time, operator skill level, and the cost of the technology weighed with its technical performance. At this point in the development of the technology, developers have investigated basic manufacturing issues since potential users attending these demonstrations may be interested in procurement and potential partners may want to manufacture or market the successful technology. 


\section{Long Term Testing}

Long term testing is essential to evaluate the technical and operational performance of the technology in the environment and mode that it will be normally operated. Parameters for evaluation are technical (e.g., accuracy, precision, sensitivity, stability, and response), operational (e.g., ease of use, portability, durability, reliability) and economic (e.g., versatility, training requirements, cost per sample). All of the technical and economic parameters must be evaluated in comparison with baseline methods. The operational parameters are often difficult to objectively compare with baseline methods, nevertheless, they are extremely important in the practical use of the technology. Metrics can be derived (e.g., time for setup, bulkiness) that are semi-quantitative and can be evaluated by users in terms of their own experience.

\section{Training}

Training potential users in the appropriate use of the technology is essential to successful transfer of the instrument. The principal requirement of a training program is that the trainee can successfully apply the technology at their site. Therefore, application specific operation of the instrument must be the main objective of training. Once that is accomplished, the more general capabilities of the technology can be addressed.

\section{Regulatory Acceptance}

A significant obstacle to successful transfer of a technology to the user community is the regulatory acceptability of the technology. If a regulator does not approve the technology, the user will not employ it. One method to achieve broad regulatory acceptability of a technology is to bring the technology through the EPA equivalency test program. This method requires a significant investment of time and money by the technology developer but results in formal EPA approval.

Another method to achieve regulatory approval for a new technology is to approach local EPA or state regulators with a specific plan for specific activities. Communicating with local regulators and other stakeholders in the early stages of planning through the active remediation effort is an important way to incorporate promising new technologies that are not yet EPA approved methods. Local regulators are generally agreeable to the use of new methods that save money providing sufficient data on the successful performance of the technology and proper and adequate contingency plans for baseline methods are provided. At SRS, an advisory committee has been established consisting of representatives from local and national regulatory groups, industry, universities, public interest groups, potential users, and SRTC personnel. The group helps select the technologies that are evaluated and reviews the evaluation strategy and specific test plans for the new technology. The inclusion of local regulatory personnel in the advisory groups facilitates the use of appropriate innovative technologies in remedial facility investigations and remediation programs at SRS. After regulators have been apprised of a candidate technology and its performance parameters, the technology is proposed in the formal site workplans. Once the technology is included in the formal Record of Decision, it is an approved technology for that particular activity. If the technology performs successfully in remediation activities, it is more likely to be accepted for future activities. SRS has successfully employed this strategy and will continue to propose appropriate technologies for site workplans. 
The final method for transferring the technology has only recently been developed by the Consortium for Site Characterization Technologies. The Consortium is headed by the EPA and consists of participants from government agencies (DOE, DOD), whose goal is to expedite the transfer of innovative environmental characterization and monitoring technologies. The Consortium is directing field tests of technologies at well-characterized waste sites using detailed and rigorous test protocol to gather a suite of data demonstrating the performance objectives of the technologies. A letter of verification will be issued by the EPA describing the instrument's performance during these tests. It is expected that this letter will rapidly expedite approval of these technologies for waste remediation activities.

\section{TECHNOLOGY DESCRIPTIONS}

\section{Short-term Field Evaluations}

Several short-term demonstrations/evaluations were performed at SRS. Developers (either on or off site ) provided their own funding and personnel and SRS provided logistic and technical support and baseline methods for comparison. SRS worked with developers to determine appropriate scenarios and to create test plans for cost effective evaluations. The objective of each test was to determine the proper niche for the technology and to expedite technology transfer.

Cone Penetrometer Based Raman Spectroscopy. The cone penetrometer has been used successfully for site characterization activities at SRS. Standard sensing tools on the cone (i.e., tip pressure, sleeve friction, capillary pressure, water and gas sampler) have been used to determine geologic profiles and contaminant distribution in the subsurface. One of the innovative uses of the standard cone penetrometer employed at the site was to map the surface of a confining zone below the water table that is theorized to control the movement of a dense non-aqueous phase liquid (DNAPL) contaminant source. To further characterize this source, a fiber optic system was installed on the cone that enabled in-situ Raman spectroscopy at the tip of the cone rod. With this system, theoretically, it is possible that DNAPL could be directly detected in the subsurface. Although the Raman spectroscopic signal could not be discerned from fluorescence noise in the field experiments at SRS, the large changes in magnitude of the confounding fluorescent signal was used to infer the presence of DNAPL at the cone tip. The two to three order of magnitude change in fluorescence intensity in areas of high DNAPL probability are probably a result of the interaction of the solvent with the geologic material in the zone. A report concerning this work is provided by Bratton et al. (1994).

Color Borehole Video Camera. A water tight, high resolution color video camera (R. J. Electronics Model RCS 800) is capable of viewing the entire circumference of a well or borehole by use of a rotating mirror. At the Savannah River Site, well video surveys were performed to examine particulate matter and translucent blobs (colloids and NAPL), screen clogging, casing discoloration due to chemical or biological activity, and screen locations.

Cone-Sipper ${ }^{\mathrm{TM}}$. The Cone-Sipper ${ }^{\mathrm{TM}}$, developed at SRS for soil gas and water sampling with cone penetrometer systems, is used to collect either continuous soil gas samples or groundwater samples during a cone push. This sampler is unique in that it does not require removing and re-inserting the rods between samples. The Cone-Sipper ${ }^{\mathrm{TM}}$ utilizes an air lift pump for water samples and has retrieved samples from depths of 180 feet at SRS. The Cone-Sipper ${ }^{\mathrm{TM}}$ 
has also been tested at DOD and DOE sites and transferred to a cone penetrometer company for further development.

POLO Directional Drilling Positioning System. The UTD, Inc. POLO system (U.S. Patent $\# 5,193,628$ ) was developed to determine accurate positioning of cone penetrometer and directional drilling tips for sampling and characterization activities and well installation. UTD, Inc. developed the original system with corporate funds and further development and demonstrations were funded by the DOE Office of Technology Development through the PRDA program. The system measures position and location based on the strain in a bending pipe. The POLO module is a 1 meter long pipe equipped with strain gauges to measure the curvature of the rod and thus the location of the drilling tip. The accuracy of the system was demonstrated at \pm $0.5 \%$ of the length of penetrometer rod in the ground (UTD, Inc., 1994).

Laser Range Finder for Water Well Level Measurements. A commercially available laser range finder was adapted at SRS for water well level measurements as a substitute for the traditional electric measuring tape. The battery powered laser range finder has proven accurate $( \pm 0.25$ inches) for water level measurements down to 60 feet. This technology can be used in situations where investigation derived waste (contaminated equipment) cannot be generated because of waste disposal issues.

ORS Inc. Accusensor Aqueous TCE Sensor. This sensor is commercially available and can measure concentrations of TCE in water to less than $5 \mu \mathrm{g} /$ liter. The instrument uses a semipermeable membrane that allows chlorinated organic vapors to penetrate and interact with a reagent that changes color in the presence of trichloroethylene or chloroform (Fujiwara reaction). The instrument has a dynamic range from 0.005 to $2.0 \mathrm{mg} / \mathrm{liter}$.

Amerasia Inc. Surface Acoustic Wave (SAW) Gas Chromatograph. This instrument uses a specially designed surface acoustic wave sensor as the detector for the gas chromatograph. This sensor responds to deviations in the amplitude and frequency caused by sorption of a chemical analyte to the surface of the SAW crystal. A packed column is used to chromatographically separate analytes ahead of the SAW sensor. The detection limit is less than 1 ppmv for several chlorinated compounds including tricholoroethylene and tetrachloroethylene.

\section{Long-term Field Evaluations}

The long-term technology evaluations underway in FY95 focus on portable gas analyzers for environmental characterization and monitoring. The objective of these evaluations is to provide regulators, users (environmental consultants, etc.), and instrument developers the opportunity to evaluate data obtained from the use of these new technologies (not yet EPA approved methods) at a field site under actual operating conditions in comparison with baseline analyses. These instruments are used in conjunction with baseline technologies for routine monitoring and deployed to field sites for characterization activities. The quantitative evaluations will be published in the future.

Portable Gas Analyzer Testing Protocol. The portable gas analyzers are used to measure chlorinated organic contaminant concentrations in soil, aqueous, soil gas, and process gas samples obtained at or near the Integrated Demonstration Site. The baseline technology (HP 
5890 Series GC) is deployed in a field laboratory at the site to verify analyses. The testing parameters include the following:

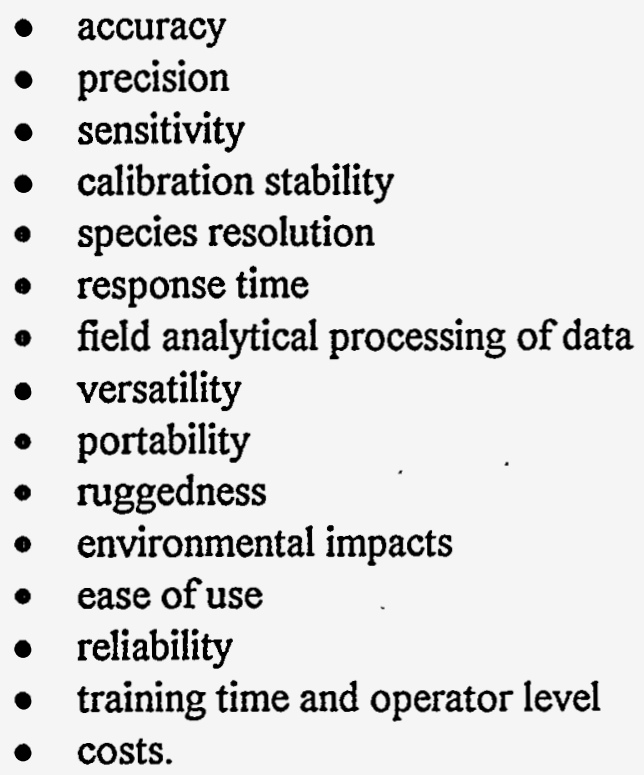

The comprehensive evaluation is based on these parameters in relation to the baseline instrument. Instrument performance is quantitatively evaluated by calibration and check standards and by analyses of field samples in comparison to baseline analyses. Figure 1 shows a plot of the HP ECD and FID detectors' response to certified gas standards over time. The response with respect to time will be tracked in a similar way for all of the instruments tested. Figure 2 is a plot comparing the concentration measurements of the field portable GCs with the reference GC. These comparisons include several types of samples obtained from the IDS. Concentration measurements are made over several ranges under different environmental conditions (e.g., temperatureand humidity extremes) and for different sample constituents. Vapor phase, as well as solid and aqueous phase samples are analyzed. The latter two types of samples will be analyzed using a modified headspace method to transfer the volatile contaminants into the gas phase. Data on less tangible parameters will also be evaluated. Figure 3 shows the coefficient of variance of the retention time of 1,1 dichloroethylene and tetrachloroethylene for different operators using different methods. This plot demonstrates the variation associated with idiosyncratic differences between operators. Although this fact of operation should not reflect on the performance of the instrument alone it does impact the quality of the measurement and may indicate subtle differences in the instrument's ease of use. Other subjective parameters will be evaluated qualitatively with a three point instrument rating. The technologies will be compared with the baseline instrument for several scenarios to determine the individual instrument's niche (Riha, et al., 1994). 


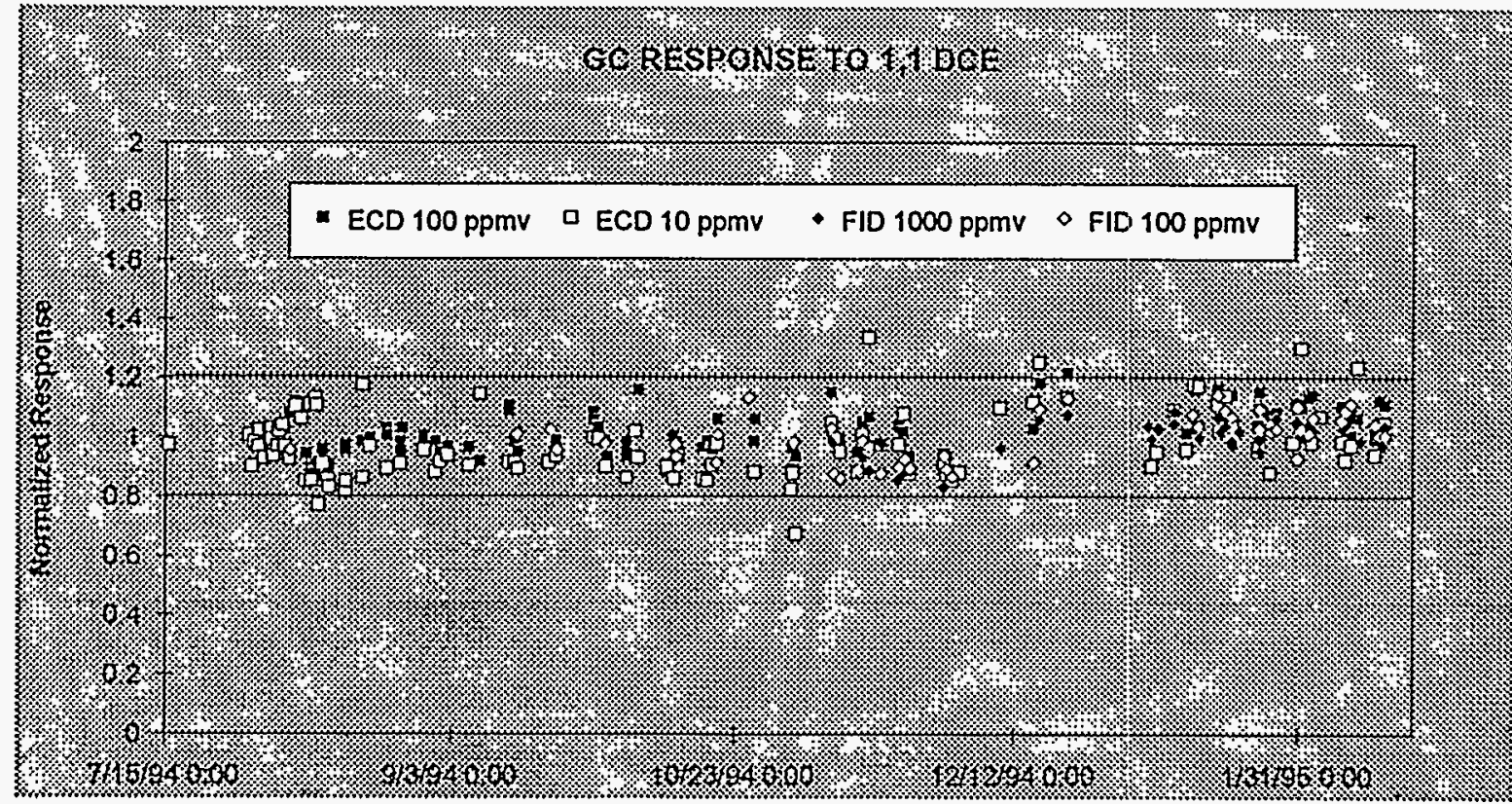

Figure 1. Response of HP detectors through time.

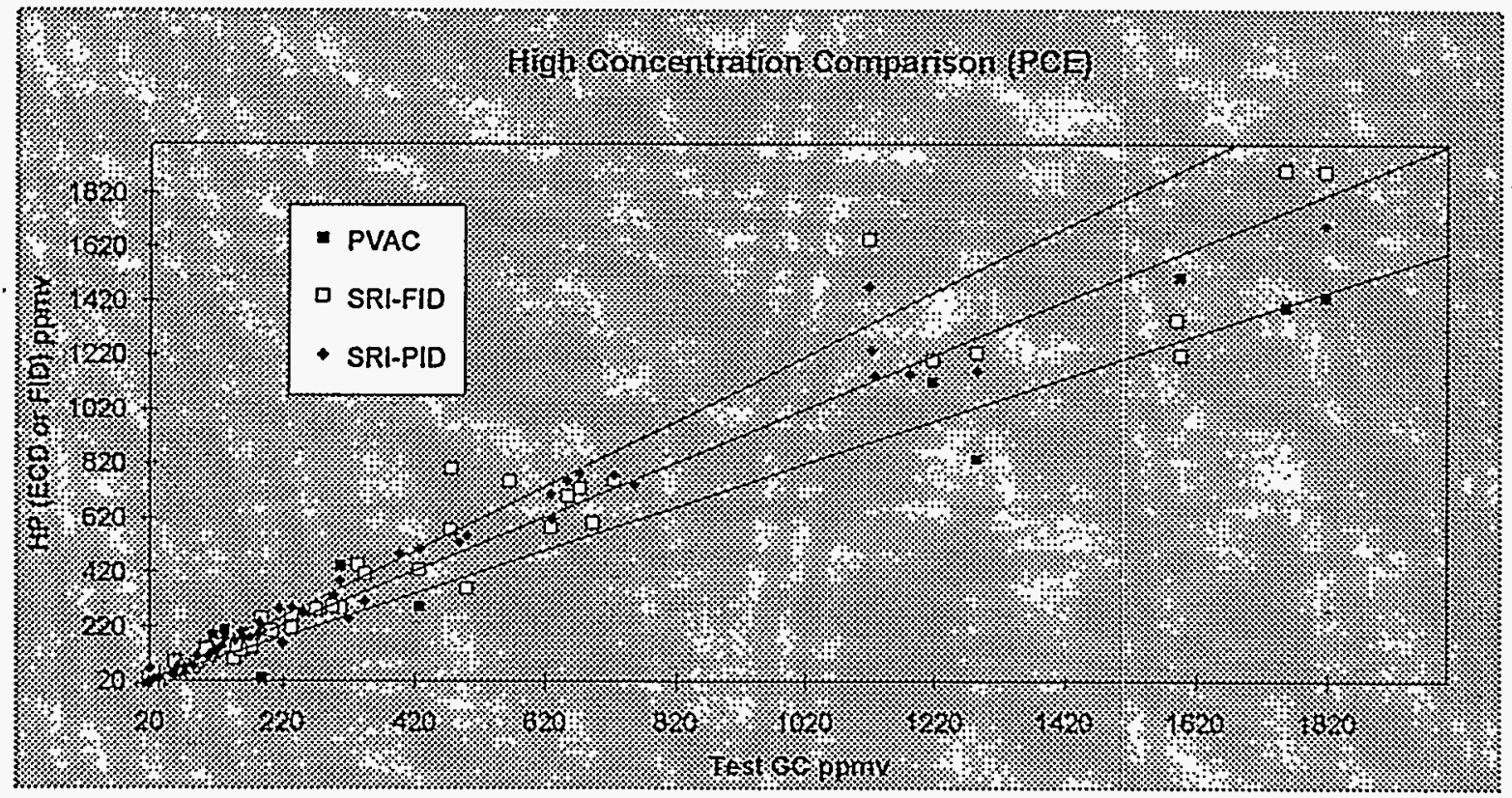

Figure 2. Comparison of Portable GCs with HP GC. 


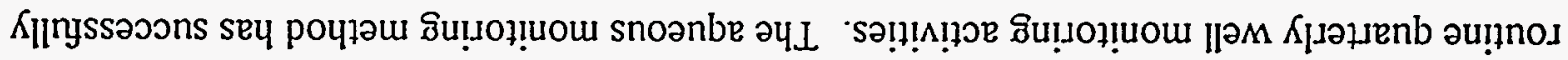

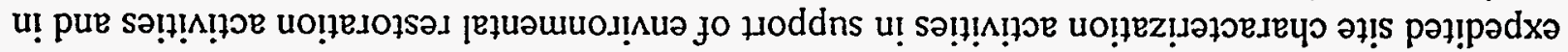

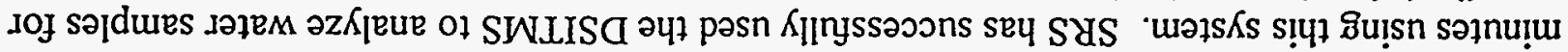

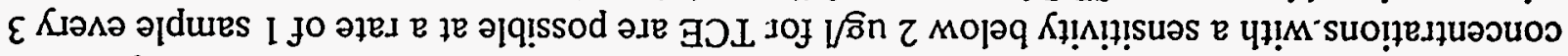

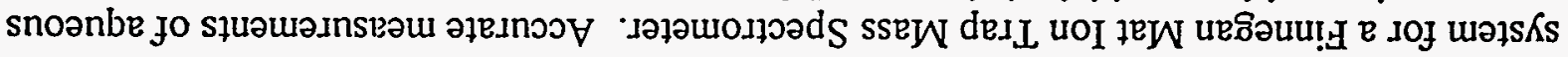

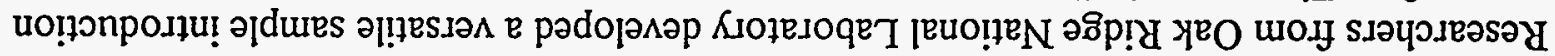

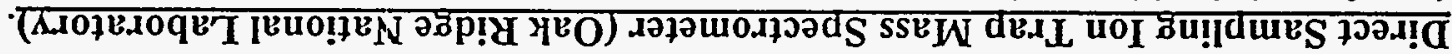

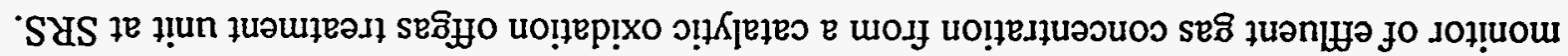

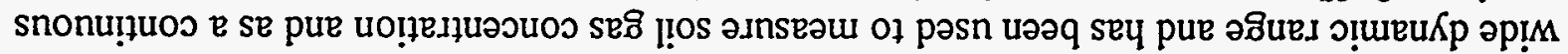

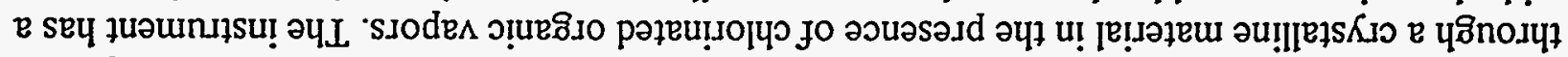

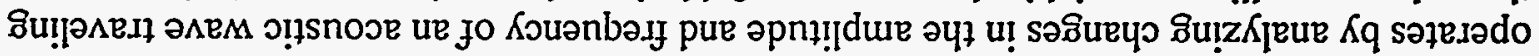

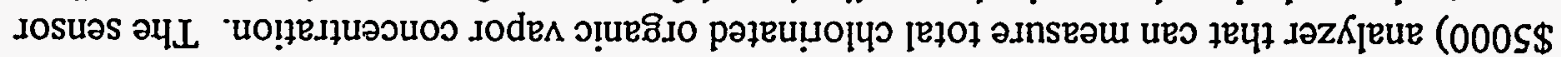

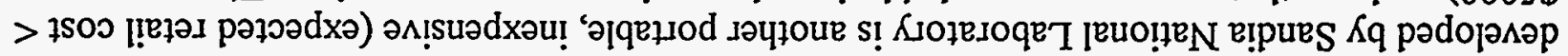

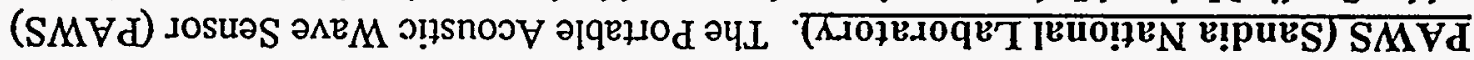

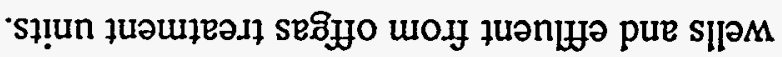

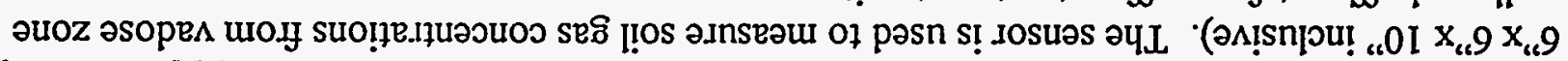

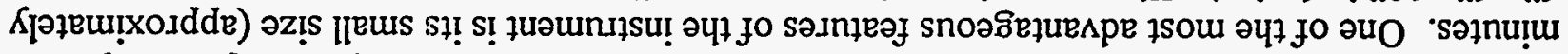

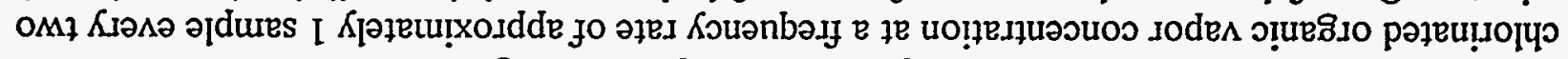

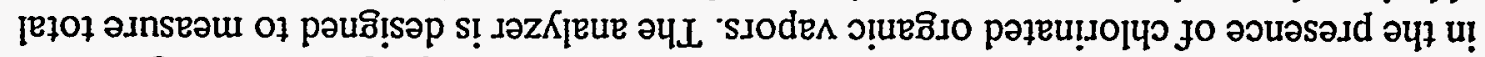

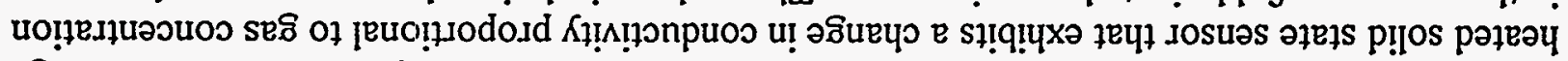

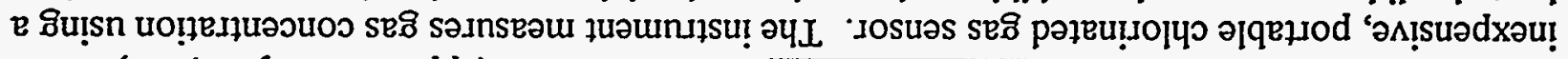
ue S! (000'9\$ א א

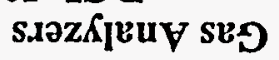

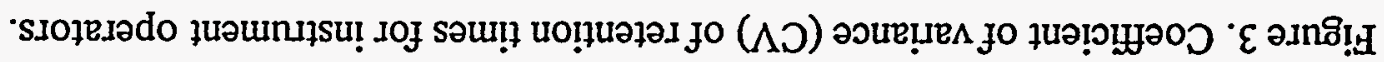

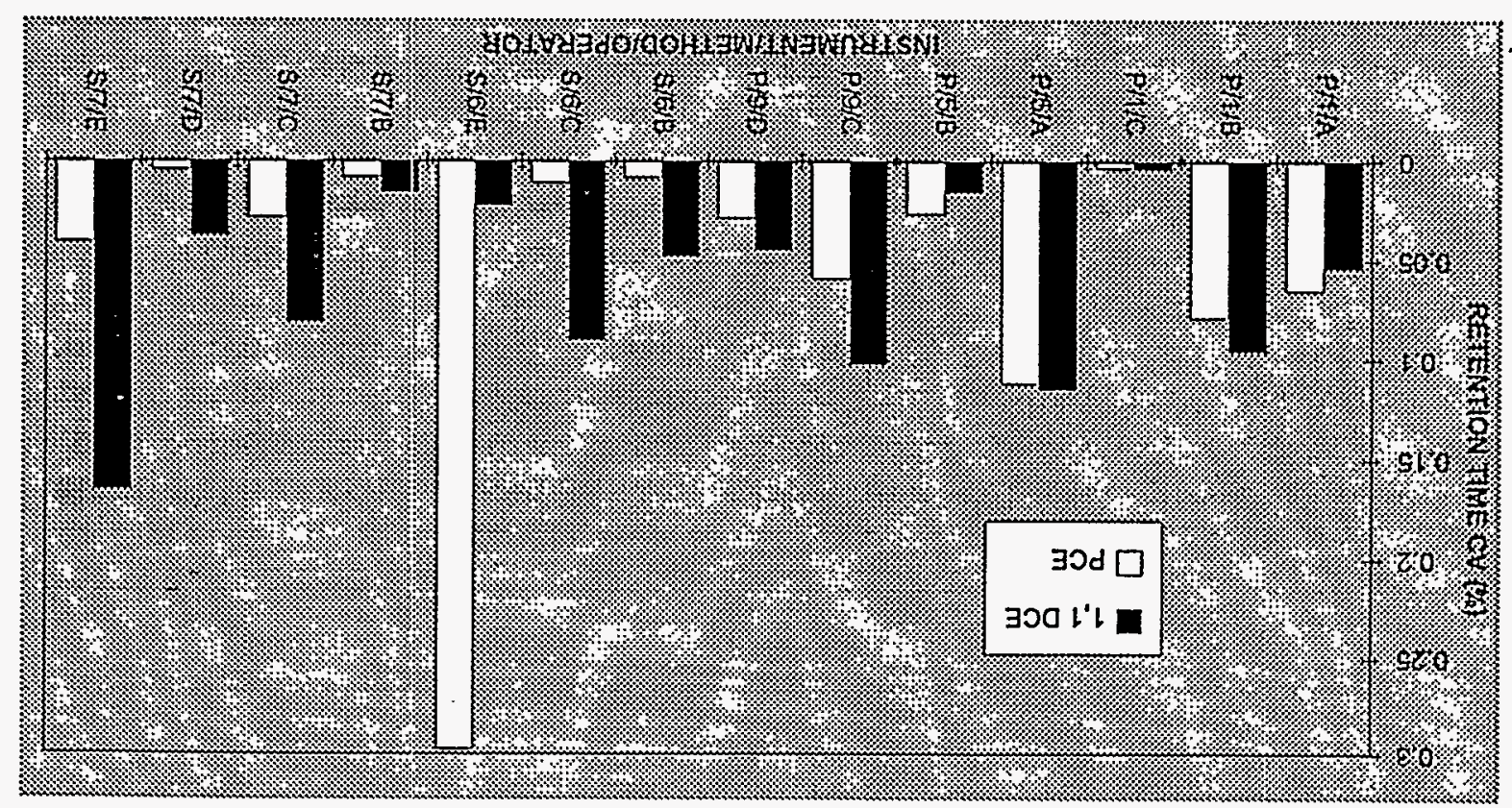


completed EPA Equivalency testing and is now an EPA approved method. A report has been completed which compares DSITMS results with baseline methods (Eddy-Dilek, et al. 1993).

10 S Plus GC (Photovac, Inc.). The 10S Plus GC (approximately $\$ 24,000$ ).is an all inclusive field deployable GC with an isothermal oven and photo-ionization detector: The instrument has a built-in carrier gas reservoir, data analysis system, and rechargeable battery. It has been successfully deployed in the field for off-gas treatment evaluation and well point concentration measurements at SRS in parallel with laboratory analyzed duplicates. The 10S Plus is suitable for field screening and quantitative analysis when a quick turn-around of monitoring and characterization data is required. Because of its all inclusive design and ability to operate for a full day without recharging the battery or carrier gas, the instrument is suitable for deployment to the field sampling site and for use on cone penetrometer systems.

Model 8610 GC (SRI, Inc.). The SRI 8610 (approximately $\$ 24,000$ ) is a transportable laboratory grade GC currently deployed in a field laboratory at the Integrated Demonstration Site. - . The instrument has flame ionization and photo-ionization detectors in series and a temperature programmable oven. The instrument has exhibited accuracy and precision comparable to the baseline $\mathrm{GC}$ in analyses performed at the site. It is suitable for deployment in field and mobile laboratories, but because of the need for separate carrier and detector gas supplies, it is not suitable for remote sites that are inaccessible by mobile labs. The instrument can be run from battery powered supplies at isothermal oven conditions.

SpectraTrak Portable GC/MS (Viking Instruments, Inc.). The Viking Instruments Inc. SpectraTrak 620 (approximately $\$ 150,000$ ) is a gas chromatograph/mass spectrometry system that provides laboratory quality mass spectroscopy in a field mobile laboratory. The instrument is ideal for analysis of samples containing unknown contaminants such as in preliminary site characterization. The SpectraTrak 620 was successfully used to rule out the presence of polychlorinatedbiphenyls (PCBs) in vacuum extraction well offgas avoiding undesirable permit modifications for six operating vapor extraction systems and offgas treatment units at SRS.

Model 1302 Multigas Analyzer (Bruel and Kiaer, Inc.). The Model 1302 (approximately $\$ 24,000$ ) is an infrared photoacoustic spectrometer capable of measuring five separate gases simultaneously. The instrument uses the unique spectral properties of the contaminants to quantify concentration. After a sample is drawn into the analysis chamber, the gas is irradiated with a pulsed mid-infrared band of light specified by a particular bandpass filter (the target component's principal absorption band). The pulsed light produces pressure waves in the chamber which are measured by sensitive microphones. Higher acoustic wave amplitudes correspond to higher concentrations.

The gas analyzer has been successfully used at SRS in many sampling scenarios with PCE and TCE concentrations in the ranges of 1 to $12,000 \mathrm{ppmv}$. Some of the sampling scenarios include continuous vapor extraction and off-gas treatment monitoring, soil flux measurements, point well concentration measurements, and depth-discrete soil vapor concentrations with a cone penetrometer system. The instrument is easily powered with a DC to $A C$ inverter and an automobile battery. The instrument has proven reliable during several unattended thirty day long 
continuous well vapor monitoring studies. During these studies, the only environmental control was a rain shield. Periodic calibration checks indicated that the calibrations were still valid after thirty days of continuous use.

A Model 1302 has been used at SRS for over a year. The instrument is user friendly, rugged in field use, and calibrations have been stable for long periods ( -3 months). It has also been used in several demonstrations at other DOE and DOD sites. The instrument was originally developed for indoor air quality measurements and process analysis. Several custom calibration and operation procedures were developed to adapt the instrument to environmental monitoring at SRS.

Model 1301 FTIR Gas Analyzer (Bruel and Kiaer, Inc.). The Bruel and Kjaer Model 1301 (approximately $\$ 40,000$ ) fourier transform infrared photoacoustic spectrometer is a rugged, portable, self-contained measurement system. It uses the same IR photoacoustic process as the Model 1302 but uses an interferometer to modulate the IR source which provides an IR spectrum . from $4000 \mathrm{~cm}^{-1}$ to $650 \mathrm{~cm}^{-1}$ wavenumbers. The instrument can be used to determine the component gases in an air or gas sample and as a monitor for repeated concentration measurements of specific components. Monitoring for up to seven gas concentrations simultaneously is possible. The instrument can be deployed at well locations and other field sampling areas by use of a mobile battery power source. Because of the automatic realignment of the optical measurement system, the 1301 is suitable for transport between field locations.

\section{SUMMARY}

The Environmental Sciences Section at the Savannah River Site has successfully demonstrated and evaluated over forty new environmental characterization and monitoring technologies. Due to the well-developed infrastructure resulting from the IDP (wells, historical characterization and monitoring data, experienced support personnel, instrumented field laboratories, and active remediation systems) the site is an ideal location for short and long term evaluations of environmental characterization and monitoring technologies. Comprehensive, objective field tests of monitoring technologies not currently used in EPA methods are being conducted in comparison to accepted baseline technologies. In addition to the technical performance of the instruments, operational parameters are being evaluated such as ease of use, operator skill required, cost, etc. All of these factors are being compiled to determine appropriate applications of the technologies. By demonstrating the niche for an innovative technology, a more rapid path to acceptance by regulators and users will be established. Appropriate innovative technologies are being included in site workplans. Inclusion of these technologies in site Records of Decision and use of the tools in remediation activities will facilitate technology transfer and ultimately reduce costs of environmental clean-up.

\section{ACKNOWLEDGMENTS}

The authors acknowledge the valuable contributions of Shirley Burdick (SRS), Brent Good (Purdue University), the SRS Environmental Technology Field Test Platform Advisory Team, Tom Higerd and Jacqueline Mowitz (Medical University of South Carolina), and Judy Clements (University of South Carolina, Aiken). This work was supported by the DOE Office of 
Technology Development. Specifically, we acknowledge the support from Kurt Gerdes (OTD Program Manager) and James Wright (DOE-SR Technical Program Officer).

This research was supported in part by an appointment to the U.S. Department of Energy Laboratory Cooperative Postgraduate Research Training Program at the Savannah River Technology Center administered by the Oak Ridge Institute for Science and Education. By acceptance of this paper, the publisher acknowledges the U. S. Government's right to retain a nonexclusive, royalty free license in and to any copyright covering this paper along with the right to reproduce, and to authorize others to reproduce all or part of the copyrighted paper.

\section{DISCLAIMER}

The report was prepared by Westinghouse Savannah River Company (WSRC) for the United States Department of Energy under contract no. DE-AC09-89SR18035 and is an account of work performed under that contract. The authors made every effort to assure the quality of this work. However, neither the United States Department of Energy, nor WSRC, nor any of their employees makes any warranty, express or implied, or assumes any legal liability or responsibility for the accuracy, completeness, or usefulness of any information, apparatus, product, or process disclosed herein, or represents that its use would not infringe privately owned rights. Reference herein to any specific commercial product, process, or service by trade name, trademark, manufacturer, or otherwise does not necessarily constitute or imply its endorsement, recommendation, or favoring by WSRC or the United States Government or any agency thereof. The views and opinions of the authors expressed herein do not necessarily state or reflect those of the United States Government or any agency thereof.

\section{REFERENCES}

Bratton, W. L., J. D. Shinn, J. Haas, and M. Carrabba. 1994. Integration of Raman Spectroscopy and Cone Penetration Technology to Characterize Chlorinated Hydrocarbon Contaminant Plumes. Applied Research Associates, Inc., South Royalton, Vermont.

Eddy, C. A., B. B. Looney, J. M. Dougherty, T. C. Hazen, and D. S. Kaback. 1991. Characterization of the Geology, Geochemistry, Hydrology, and Microbiology for the In-Situ Air Stripping Demonstration Site at the Savannah River Site (U), WSRC-RD-91-21. Westinghouse Savannah River Company, Aiken, SC.

Eddy-Dilek, C. A., J. Rossabi, and M. A. Keenan. 1993. The Direct Sampling Ion Mass Spectrometer for the Rapid Analysis of Volatile Organic Contaminants in Groundwater Samples (U), WSRC-TR-93-563. Westinghouse Savannah River Company, Aiken, SC.

Kaback, D. S., B. B. Looney, J. C. Corey, L. M. Wright, and J. L. Steele. 1989. "Horizontal Wells for In-Situ Remediation of Groundwater and Soils," in Proceedings of the Third National Outdoor Action Conference on Aquifer Restoration, Groundwater Monitoring, and Geophysical Methods. Association of Groundwater Scientists and Engineers, Las Vegas.

Looney, B. B., J. Rossabi, D. M. Tuck, C. L. Bergren, R. Van Pelt, W. E. Jones, A. E. Stevenson, and B. S. Kristiansen. 1992. Assessing DNAPL Contamination in AM Area, 
SRS: Phase I Results (U), WSRC-RP-1302. Westinghouse Savannah River Company, Aiken, SC.

Looney, B. B., T. C. Hazen, D. S. Kaback, and C. A. Eddy. 1991. Full Scale Field Test of the In-Situ Air Stripping Process at the Savannah River Integrated Demonstration Test Site (U), WSRC-RD-91-22. Westinghouse Savannah River Company, Aiken, SC.

Riha, B. D., J. Rossabi, B. E. Pemberton, and C. P. May. 1994. Environmental Technology Field Test Platform Conceptual Test Plan. Westinghouse Savannah River Company, Aiken, SC.

UTD, Inc. 1994. The UTD POLO System, Bulletin POLO-4A. UTD Inc., Newington, Virginia.

WSRC. 1993. Demonstration of Innovative Monitoring Technologies at the Savannah River Integrated Demonstration Site (U), WSRC-TR-93-671. Westinghouse Savannah River Company, Aiken, SC.

WSRC. 1994. Environmental Protection Department's Well Inventory (U), ESH-EMS-930262. Westinghouse Savannah River Company, Aiken, SC. 